\title{
Manfred Liebel i Urszula Markowska-Manista, Prawa dziecka w kontekście międzykulturowości. Janusz Korczak na nowo odczytany, Warszawa, Wydawnictwo Akademii Pedagogiki Specjalnej, 2017, ss. 242.
}

\section{EWA SOWA-BEHTANE}

Akademia Ignatianum w Krakowie, Wydziat Pedagogiczny, Katedra Pedagogiki Społecznej, ul. Kopernika 26, 31-501 Kraków.

ORCID 0000-0002-0190-0567,E-mail: ewasowa@tlen.pl

SŁOWA KLUCZOWE: prawa dziecka, badania nad dzieciństwem, Janusz Korczak, międzykulturowość

Recenzowana książka Prawa dziecka w kontekście międzykulturowości Janusz Korczak na nowo odczytywany jest zbiorem tekstów poświęconych współczesnej problematyce praw dzieci w warunkach międzykulturowości oraz recepcji idei Janusza Korczaka w kontekście naukowobadawczym. Publikacja powstała w ramach polsko-niemieckiego projektu: „PolnischDeutsche wissenschaftliche Dialoge über Kinderrechte, Janusz Korczak und Migration/ Polsko-niemieckie naukowe dialogi o prawach dziecka, Januszu Korczaku i migracji”, który otrzymał dofinansowanie Polsko-Niemieckiej Fundacji na rzecz Nauki/Deutsch-Polnische Wissenschaftsstiftung.

Praca ta jest interesującym głosem w dyskusji o prawach dziecka i ważną pozycją w kategorii badań nad dzieciństwem. Pozwala także przyjrzeć się zróżnicowanym polom problemowym i wielości podejść do niezwykle bogatego dorobku Janusza Korczaka, odnosząc go do sytuacji wielokulturowości. Autorzy pokazują, iż postać Korczaka jest ponadczasowa. Książka inspiruje czytelnika do własnych przemyśleń na temat problemów praw dzieci, współczesnych wyzwań i nieodkrytych bądź pomijanych możliwości dialogu na tematy istotne w rożnych przestrzeniach edukacyjnych. Recenzowana książka odnosi prace i postawy Janusza Korczaka do ważnych kwestii pedagogicznych organizujących się wokół kategorii praw dzieci, dzieciństwa i międzykulturowości. Autorzy analizują różne kwestie, dzielą się swoimi spostrzeżeniami, pokazują dobre praktyki.

Monografia jest zbudowana z trzech części. Część 1. rozpoczyna się artykułem Przetrwać z nadzieja w obliczu rozpaczy $i$ bezsilności. Refleksje o Januszu Korczaku, w którym opisane zostało życie Korczaka w aspekcie teorii resilience, koncentrującej się na wyjaśnianiu fenomenu, jakim jest dobre funkcjonowanie niektórych jednostek mimo niekorzystnych warunków życia, przeciwności losu lub zdarzeń traumatycznych. Ciekawe odniesienie życia 
Korczaka do teorii resilience pozwala na uzyskanie odpowiedzi na pytanie: w jaki sposób udało mu się przetrwać w tylu stresujących sytuacjach? W tekście znajdujemy konkluzję, że to możliwość skoncentrowania na dzieciach swojej energii życiowej miała dla Korczaka istotne znaczenie. Dzięki niej okrucieństwa i trudności, jakie towarzyszyły mu w życiu, nie zniechęciły go do dalszych działań. W drugim artykule Manfred Liebel opisał historię praw dziecka oraz ruchy na rzecz praw dziecka, a w kolejnym Janusz Korczak i prawa dziecka jako zdolność sprawcza wyjaśnił dlaczego, zdaniem Korczaka, posiadanie własnych praw przez dzieci jest koniecznością, jak Korczak pojmował kwestię zdolności sprawczej, ideę samoorganizacji czy też samorządu dzieci. Ważnym elementem tego artykułu, jak i całej pracy, jest cytowanie wielu dzieł Janusza Korczaka. W kolejnym artykule Manfred Liebel opisuje Moskiewską Deklarację Praw Dziecka, która - jak napisał autor - „wyraża nurt w historii praw dziecka, który nawet obecnie nie jest powszechnie akceptowany. Odzwierciedla emancypacyjne, osadzone w kontekście życia podejście do praw dziecka, w którym dzieci traktowane są poważnie nie tylko jako podmioty prawne, lecz również społeczne oraz odgrywają ważną rolę jako aktorzy społeczni i polityczni” (s. 85). Dzieci powinny więc być traktowane na równi z innymi jako jednostki potrafiące oddziaływać na własne środowisko życia.

Część 2. Dylematy praw dzieci w międzykulturowości rozpoczyna artykuł Urszuli Markowskiej-Manisty „Najlepszy interes” dzieci marginalizowanych i ich partycypacja. Lekcje z pedagogiki Janusza Korczaka, w którym autorka zaznacza, że „Korczak był pionierem w dziedzinie praw dziecka i zwolennikiem wieloaspektowego podejścia do ich funkcjonowania w świecie zdominowanym przez dorosłych. On nadał dzieciom i dorosłym rolę strażników praw dziecka, a jednocześnie starał się zwrócić uwagę świata na wzajemną - kluczową zależność dorosłych i dzieci” (s. 104). W kolejnym artykule - „,Białe” dzieci-, ,czarne” dzieci. Rozważania nad powieścia dla dzieci o małym królu Maciusiu Janusza Korczaka Manfred Liebel przestawia powieść o królu Maciusiu, w której Korczak udaje się w tereny „obcych ludów”. Powieść ta stwarza okazję do refleksji nad jego rozumieniem „konfliktów rasowych”. Trzeci artykuł, autorstwa Manfreda Liebel'a, przedstawia ciekawe badania przeprowadzone w Anglii, Szkocji i Walii wśród dzieci i młodzieży pomiędzy 12. a 17. rokiem życia, które wskazują, iż wszystkie doświadczyły dyskryminacji ze względu na wiek, w tym gdy chciały skorzystać z usług pogotowia medycznego i innej pomocy, czy korzystając z transportu publicznego i sklepów.

Część 3. Dzieciństwa ponad granicami rozpoczyna artykuł Manfreda Liebel'a, w którym przestawione zostały kulturowe wariacje form partycypacji dzieci. Kolejny artykuł tego autora Dzieci bez dzieciństwa? Konceptualizacje dzieciństw(a) w krajach Globalnego Poludnia w świetle teorii postkolonialnych odpowiada na pytanie: czym są teorie postkolonialne oraz jak wygląda postkolonialna polityka wobec dzieci? Autor podsumowuje, że „ruchy emancypacyjne dzieci z krajów Globalnego Południa są owocem kreatywności zdekolonizowanej, unikalnej, nowej kultury opartej na równym, międzykulturowym dialogu i wzajemnej akceptacji” (s. 199). Z kolei Urszula Markowska-Manista w artykule Pisane i niepisane prawa dzieci z ludności rdzennej w Afryce Środkowej. Pomiędzy wolnościa ,tradycji” a zniewoleniem dla „,rozwoju” 
opisuje formy marginalizacji, jakiej doświadczają ludy Ba'Aka. W związku z brakiem respektowania ich praw, które zawierają się choćby w ich partycypacji w podejmowaniu decyzji o ich rozwoju, ich głos wciąż pozostaje niesłyszalny. Ostatni artykuł Manfreda Liebel'a Badania realizowane przez dzieci: doświadczenia z dziećmi „,niedopasowanymi” ukazuje nam modele badań nad dzieciństwem. Nie zawsze możliwe jest wyraźne rozdzielenie badań z dziećmi od badań realizowanych przez dzieci; w praktyce oba modele mogą się pokrywać, jak i wzajemnie uzupełniać. „Badania realizowane przez dzieci mogą odbywać się w różnych kontekstach. Mogą być realizowane w ramach pedagogicznych działań szkoły lub instytucji opieki dziennej, na przykład poprzez wspólne dyskusje z dziećmi lub wprowadzenie do lekcji elementów małych projektów badawczych. Mogą one mieć charakter zabawy (...). Mogą być też realizowane przez dzieci i młodzież, która (chce) się zorganizować w celu zbadania własnej sytuacji czy sytuacji innych dzieci, głębszego zrozumienia istniejących problemów i znalezienia rozwiązań tychże problemów. W większości przypadków tego rodzaju inicjatywy określane są mianem „,badań zaangażowanych” (ang. action research), gdyż mają na celu nie tylko lepsze poznanie rzeczywistości, lecz także znalezienie rozwiązań własnych problemów oraz problemów innych" (s. 229).

Recenzowana publikacja jest warta polecenia z kilku powodów. Po pierwsze przywołuje postać Janusza Korczaka, porządkuje wiedzę o prawach dziecka oraz ukazuje zagraniczne badania z tego zakresu. Taka zawartość pracy pozwala na stwierdzenie, że jest to innowacyjne dzieło wniesione do polskiej (i nie tylko) pedagogiki. Po drugie, to studium teoretyczne stanowi doskonały punkt wyjścia dla pedagogicznych eksploracji empirycznych. Po trzecie, praca napisana została przystępnym językiem, ma czytelny układ i bardzo bogate zestawienie bibliograficzne. Należy zgodzić się z recenzentką wydawniczą pracy - dr hab. Ewą Jarosz, która wskazuje, że „książka ta ma ogromny potencjał inspiracyjny dla polskich badaczy prezentując wiele ciekawych i niemal »dziewiczych« dla polskiego dyskursu wątków i obszarów eksploracji. Uważam ją też za szczególnie wartościową w perspektywie w zasadzie dopiero kreowania się w Polsce formacji badawczej jaką są badania nad dzieciństwem".

Polecam tę publikację, w przekonaniu, że stanie się ona źródłem refleksji pedagoga czy specjalisty z innych dyscyplin nauk społecznych i humanistycznych, ale także praktyków edukacji, zainteresowanych różnorodnością współczesnych obszarów myślenia o prawach dzieci oraz o międzykulturowości.

1 Fragment recenzji dr hab. Ewy Jarosz (okładka). 